\title{
Analysis of Moral Reasoning of Teachers and the Students with Respect to Kohlberg's Theory of Moral Development
}

\author{
Muhammad Hafeez ${ }^{1, ~ *, ~ F a t i m a ~ T a h i r a ~}{ }^{1}$, Qaisar Abbas Kazmi ${ }^{2}$, Muhammad Zahid Hussain ${ }^{3}$ \\ ${ }^{1}$ Department of Science Education, Allama Iqbal Open University, Islamabad, Pakistan \\ ${ }^{2}$ Dera Ghazi Khan Campus, Allama Iqbal Open University, Islamabad, Pakistan \\ ${ }^{3}$ Government College for Boys, Dera Ghazi Khan, Pakistan \\ Email address: \\ mh9589041@gmail.com (M. Hafeez) \\ ${ }^{*}$ Corresponding author
}

\section{To cite this article:}

Muhammad Hafeez, Fatima Tahira, Qaiser Abbas Kazmi, Muhammad Zahid Hussain. Analysis of Moral Reasoning of Teachers and the Students with Respect to Kohlberg's Theory of Moral Development. International Journal of Neurologic Physical Therapy. Vol. 6, No. 1, 2020, pp. 7-16. doi: 10.11648/j.ijnpt.20200601.12

Received: March 21, 2020; Accepted: April 9, 2020; Published: August 27, 2020

\begin{abstract}
Moral development of persons is a basic aim of education. According to Islamic teachings, success and failure of a person is judged on moral basis in this world and the hereafter. This study focuses on analysis of moral reasoning of teachers and the students with respect to Kohlberg's theory of moral development. The target population for this study was teachers and students of secondary schools of district Dera Ghazi Khan. Twenty secondary schools are randomly selected from district Dera Ghazi Khan. Three (03) teachers and ten (10) students from each school are selected using random sampling method. The total sample size will be 60 teachers and 200 students. Data is selected by DIT (defining issue test). The collected data is analyzed through descriptive analysis and chi-square test applied using SPSS. The results reveal that the participants reasoned predominantly at the conventional level of Kohlberg's moral reasoning which found that there is no significant difference between the view of teachers and students towards moral reasoning.
\end{abstract}

Keywords: Koherlberg’s Theory, Moral Reasoning, Moral Development, DIT, Teacher

\section{Introduction}

A serious challenge of the present age is to cultivate the morally developed, sensible and responsible citizens [1-3]. The origins for altruism must be looked for in the first behaviors and feelings of the child and observe its evolution until the moral fundaments are constituted. The big issue is that between this behavior and feelings, and the moral, there is an adult authority intervention, which produces a "shortcircuit" in the evolutionary course; besides that, the problem is overcoming the internal difficulties of his/her evolution. Such evolution consists of overcoming the initial structural nature to build up another one qualitatively different [2-5]. Much research and philosophical reflection has been done on religiosity and motivation toward moral and pro-social behaviour [6-15]. Teachers are the most imperative tool in refining schools and contributing to student accomplishment $[16,17]$. Kohlberg's theory on moral development postulates that ethical reasoning is not static, but rather a person is able to move up from one stage to the next. Therefore, we each have the ability to move to Kohlberg's Stage 5 when faced with moral dilemmas. Any student who uses technology can be faced with a technology-related moral dilemma, and it is important to understand ethical training and assessment of information technology students in order for ethical development to take place [18]. In a quantitative descriptive study [19] examined the moral reasoning development levels of undergraduate teacher education students. To measure their moral reasoning, he employed the DIT instrument of James Rest. Results revealed that moral reasoning development scores were statistically significantly different. Thus, a substantial amount of research on the moral reasoning of undergraduate and graduate students has been undertaken in a wide variety of cultural groups, predominantly, however, in the United States [19, 20]. However, there is a dearth of empirical research regarding moral development of Muslim undergraduate and graduate 
students. To the best knowledge of the present authors, based on a comprehensive review of relevant literature, only few studies have been attempted on high schools and undergraduate students from Arab Muslim cultures [21-26]. Nettleton [27] conducted a study to explore students' moral reasoning development while in college. The findings suggest both similarities and differences across gender, which may shed light on possible gender differences in moral reasoning outcomes in college. Better understanding of the role that gender plays in student choices could inform college administrators around issues that impact student participation and, therefore, meaningful development while in college. Previous studies revealed that those who have high moral sensitivity are children who are against moral disengagement and oppose immoral acts, for example, intimidation against humans. It is also known that moral disengagement is positively related to aggression [28-30] and antisocial behavior [31].

Stages of Moral Development

Based upon (Piaget [32] conception of moral reasoning, Kohlberg conducted empirical and longitudinal studies which revealed six developmental stages allotted to three moral levels. Kohlberg demonstrated an evolution through the stages of moral reasoning development and delineated six stages within three different levels as follows:

i. Pre-Conventional Level

Stage 1: The Punishment and Obedience OrientationOrientation to punishment, obedience, and physical and material power. Rules are obeyed to avoid the consequence of punishment. Avoidance of punishment and unquestioning deference to power are valued in their own right, not in terms of respect for an underlying moral order supported by punishment and authority. Stage 2: The Instrumental Relativist Orientation Naive instrumental hedonistic orientation. The child conforms in order to obtain rewards. Right action consists of that which instrumentally satisfies one's own needs and occasionally the needs of others. Human relations are viewed in terms like those of the market place. Elements of fairness, reciprocity, and equal sharing are present, but they are always interpreted in a physical or pragmatic way.

ii. Conventional Level

Stage 3: The Interpersonal Concordance of 'Good BoyNice Girl' Orientation- Good behavior is that which pleases or helps and is approved by others. There is much conformity to stereotypical images of what is majority or natural behavior. Behavior is frequently judged by intention. $\mathrm{He}$ means well becomes important for the first time, and a person earns approval by being nice.

Stage 4: The Law and Order Orientation- This is an orientation toward authority, fixed rules, and the maintenance of the social or religious order. Right behavior consists of doing one's duty, showing respect for authority, and maintaining the given social order for its own sake.

iii. Post-Conventional, or Principled Level

Stage 5: The Social-Contract Legalistic Orientation-
Generally characterized with utilitarian overtones. Right action tends to be defined in terms of general individual rights and in terms of standards that have been critically examined and agreed upon by the whole society. Emphasis is upon equality and mutual obligation within a democratic order. There is an awareness of relativism of personal values and the use of procedural rules in reaching consensus. Special significance given to the legal point of view, but with an awareness that law can be changed when considering societal utility.

Stage 6: The Universal Ethical Principle OrientationRight is defined by the decision of conscience in accord with self-chosen ethical principles appealing to logical comprehensiveness, universality, and consistency. These principles are not concrete like the Ten Commandments but are more abstract like the Golden Rule [33-38].

\section{Methodology}

To focusing the above mentioned criteria, the 20 secondary schools were selected from targeted population randomly. Among these 20 secondary schools, Three (03) teachers and ten (10) students from each school were nominated applying random sampling process. The total sample size included 60 teachers and 200 students from all secondary schools of District Dera Ghazi Khan.

\subsection{Data Collection}

The data was collected using questionnaire from respondents which were selected from nominated 20 secondary schools in District D. G. Khan. So, Data was collected by distributing questionnaire to students and teachers by personal visits to respective schools.

\subsection{Data Analysis}

The collected data was analyzed by using SPSS. Frequency distributing, mean and standard deviation were applied. The composed facts were examined using SPSS-18 and mean, standard deviation and independent sample t-test was applied to examine the data as a statistical method.

\section{Results and Discussion}

For the Interpretation of the results we use SDA $=1.00-1.80$, $\mathrm{DA}=1.81-2.60, \mathrm{UD}=2.61-3.40, \mathrm{~A}=3.41-4.20, \mathrm{SA}=4.21-5.00$. Following table is based on the data which was collected from respondents which were the teachers and the students of secondary school situated in district D. G. Khan. Table consists on the questionnaire statements which were based on five point likert's scale arranged from Strongly disagree (SDA) to Strongly agree (SA), Mean (M) and standard deviation (SD). Data which was collected from the respondents showed in table 1, which show the each statement of the question and its statistical analysis and findings. 
Table 1. Respondents (teachers and students) of secondary school in district D. G. Khan.

\begin{tabular}{|c|c|c|c|c|c|c|c|c|c|}
\hline Sr. No & Statements & $\mathbf{f} / \%$ & SDA & DA & UD & $\mathbf{A}$ & SA & $\mathbf{M}$ & SD \\
\hline \multirow{2}{*}{1} & \multirow{2}{*}{$\begin{array}{l}\text { Is Aslam brave sufficient to risk receiving trapped } \\
\text { for robbery }\end{array}$} & $\mathrm{f}$ & 32 & 68 & 33 & 65 & 63 & \multirow{2}{*}{1.77} & \multirow{2}{*}{0.42} \\
\hline & & $\%$ & 12.3 & 26.1 & 12.6 & 24.9 & 24.1 & & \\
\hline \multirow{2}{*}{2} & \multirow{2}{*}{$\begin{array}{l}\text { Doesn't it only natural for darling dad to care so } \\
\text { much for his domestic that he would steal? }\end{array}$} & $\mathrm{f}$ & 43 & 83 & 35 & 46 & 54 & \multirow{2}{*}{2.27} & \multirow{2}{*}{0.918} \\
\hline & & $\%$ & 16.5 & 31.8 & 13.4 & 17.6 & 20.7 & & \\
\hline \multirow{2}{*}{3} & \multirow{2}{*}{ Shouldn't the group's laws be supported? } & $\mathrm{f}$ & 105 & 53 & 27 & 40 & 36 & \multirow{2}{*}{1.33} & \multirow{2}{*}{0.475} \\
\hline & & $\%$ & 40.2 & 20.3 & 10.3 & 15.3 & 13.8 & & \\
\hline \multirow{2}{*}{4} & \multirow{2}{*}{$\begin{array}{l}\text { Does Aslam identify a decent formula for making } \\
\text { soup form tree bay? }\end{array}$} & $\mathrm{f}$ & 94 & 75 & 32 & 42 & 18 & \multirow{2}{*}{1.37} & \multirow{2}{*}{0.486} \\
\hline & & $\%$ & 36 & 28.7 & 12.3 & 16.1 & 6.9 & & \\
\hline \multirow{2}{*}{5} & \multirow{2}{*}{$\begin{array}{l}\text { Does the rich man have any lawful correct to store } \\
\text { food when other persons are hungry? }\end{array}$} & $\mathrm{f}$ & 39 & 24 & 23 & 59 & 116 & \multirow{2}{*}{1.42} & \multirow{2}{*}{0.497} \\
\hline & & $\%$ & 14.9 & 9.2 & 8.8 & 22.6 & 44.4 & & \\
\hline \multirow{2}{*}{6} & \multirow{2}{*}{$\begin{array}{l}\text { Is the reason of Aslam to take for himself or to } \\
\text { giveaway for his family? }\end{array}$} & $\mathrm{f}$ & 26 & 65 & 34 & 49 & 87 & \multirow{2}{*}{1.85} & \multirow{2}{*}{0.404} \\
\hline & & $\%$ & 10 & 24.9 & 13 & 18.8 & 33.3 & & \\
\hline \multirow{2}{*}{7} & \multirow{2}{*}{$\begin{array}{l}\text { What standards are going to be the foundation for } \\
\text { communal collaboration? }\end{array}$} & $\mathrm{f}$ & 106 & 73 & 29 & 35 & 16 & \multirow{2}{*}{1.32} & \multirow{2}{*}{0.469} \\
\hline & & $\%$ & 40.6 & 28 & 1.1 & 13.4 & 6.9 & & \\
\hline \multirow{2}{*}{8} & \multirow{2}{*}{$\begin{array}{l}\text { Is the essence of consumption reconcilable with the } \\
\text { liability of theft? }\end{array}$} & $\mathrm{f}$ & 52 & 49 & 77 & 35 & 48 & \multirow{2}{*}{2.75} & \multirow{2}{*}{0.474} \\
\hline & & $\%$ & 19.9 & 18.8 & 29.5 & 13.4 & 18.4 & & \\
\hline 9 & Does the rich man merit to & $\mathrm{f}$ & 60 & 43 & 36 & 49 & 72 & 323 & 1386 \\
\hline 9 & be raided for being so desirous? & $\%$ & 23 & 16.5 & 13.8 & 18.8 & 27.6 & 3.23 & 1.580 \\
\hline & Isn't private stuff an institute to allow the rich to & $\mathrm{f}$ & 63 & 80 & 39 & 37 & 41 & & \\
\hline 10 & activity the poor? & $\%$ & 24.1 & 30.7 & 14.9 & 14.2 & 15.7 & 2.94 & 1.409 \\
\hline & Would theft bring about more entire decent for & $\mathrm{f}$ & 51 & 68 & 34 & 46 & 61 & & \\
\hline 11 & everyone worried or not? & $\%$ & 19.5 & 26.1 & 13 & 17.6 & 23.4 & 2.42 & 1.480 \\
\hline & Are laws receiving in the way of the most & $\mathrm{f}$ & 98 & 52 & 30 & 48 & 33 & & \\
\hline 12 & elementary right of any fellow of society? & $\%$ & 37.5 & 19.9 & 11.5 & 18.4 & 12.6 & 2.29 & 1.292 \\
\hline
\end{tabular}

Table 2. Aslam brave sufficient to risk receiving trapped for robbery.

\begin{tabular}{lllll}
\hline Option & Frequency & Percentages & Mean & Standard Deviation \\
\hline Strongly Disagree & 31 & 12.3 & & \\
Disagree & 68 & 26.1 & 1.77 & 0.42 \\
Undecided & 33 & 12.6 & & \\
Strongly Agree & 65 & 24.9 & & \\
Agree & 63 & 24.1 & 100 & \\
Total & 260 & & & \\
\hline
\end{tabular}

Table 2 showed that more than $50 \%$ responded agreed the said statements and admitted that respondents verified the items and expressed their feelings with regards to Kohlberg's theory. While some odd respondents refused to show their response. It also showed that some participants did not their willingness about the statements. Therefore it is concluded that Kohlberg's theory had positive impact on the achievement level of the learners and it would be appropriate if its application may be imposed in school level as well as higher level. Getting caught for stealing.

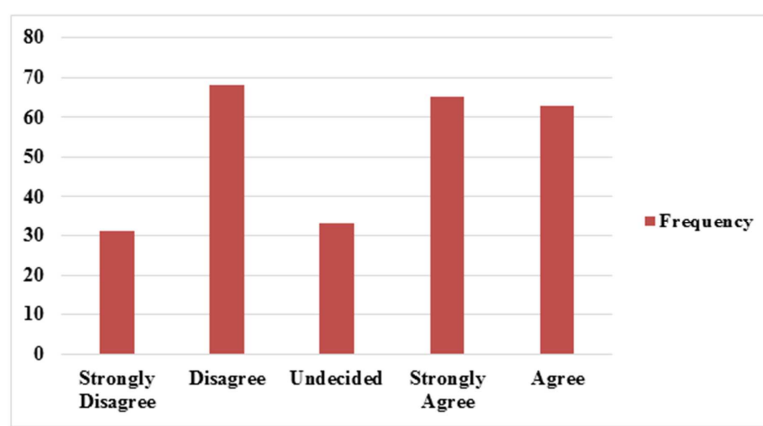

Figure 1. Aslam brave sufficient to risk receiving trapped for robbery.
Table 3. Doesn't it only natural for darling dad to care so much for his domestic that he would steal.

\begin{tabular}{lllll}
\hline Option & Frequency & Percentages & Mean & $\begin{array}{l}\text { Standard } \\
\text { Deviation }\end{array}$ \\
\hline Strongly Disagree & 43 & 16.5 & & \\
Disagree & 82 & 31.8 & & \\
Undecided & 35 & 13.4 & 2.27 & 0.918 \\
Strongly Agree & 46 & 17.6 & & \\
Agree & 54 & 20.7 & & \\
Total & 260 & 100 & & \\
\hline
\end{tabular}

Table 3 showed that more than 50\% responded agreed the said statements and admitted that respondents verified the items of Aslam and expressed their feelings with regards to Kohlberg's theory. While some of respondents refused to show their response. It also showed that some participants did not their willingness about the statements. Therefore it is concluded that Kohlberg's theory had positive impact on the achievement level of the learners and it would be appropriate if its application may be imposed in school level as well as higher level. Getting caught for stealing”. 


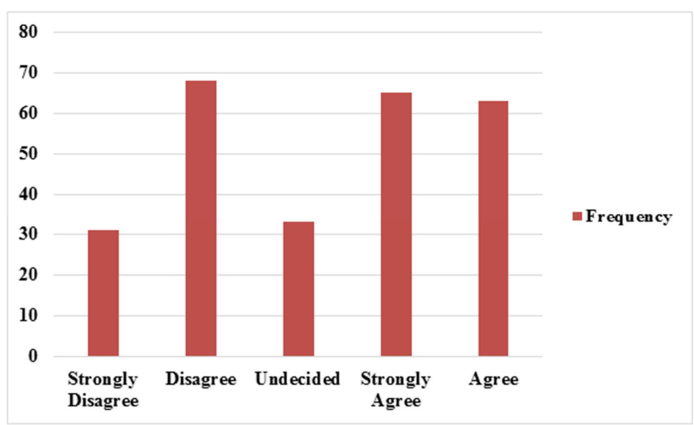

Figure 2. Doesn't it only natural for darling dad to care so much for his domestic that he would steal.

Table 4. Shouldn't the group's laws be supported.

\begin{tabular}{lllll}
\hline Option & Frequency & Percentages & $\begin{array}{c}\text { Mean } \\
\text { Value }\end{array}$ & $\begin{array}{c}\text { Standard } \\
\text { Deviation }\end{array}$ \\
\hline Strongly disagree & 104 & 40.2 & & \\
Disagree & 53 & 20.3 & & \\
undecided & 27 & 10.3 & 1.33 & 0.475 \\
Strongly agree & 40 & 15.3 & & \\
Agree & 36 & 13.9 & & \\
Total & 260 & 100 & & \\
\hline
\end{tabular}

Table 4 showed that more than $50 \%$ responded agreed the said statements and admitted that respondents verified the items of Aslam and expressed their feelings with regards to Kohlberg's theory. While some of respondents refused to show their response. It also showed that some participants did not their willingness about the statements. Therefore it is concluded that Kohlberg's theory had positive impact on the achievement level of the learners and it would be appropriate if its application may be imposed in school level as well as higher level. Getting caught for stealing.

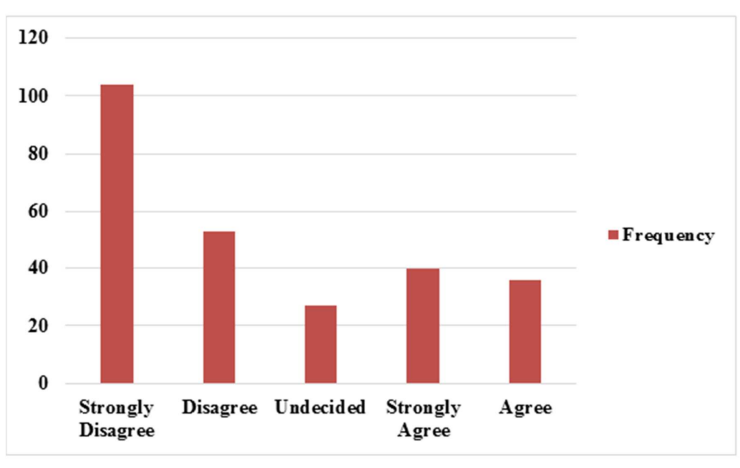

Figure 3. Shouldn't the group's laws be supported.

Table 5. Does Aslam identify a decent formula for making soup form tree bay.

\begin{tabular}{lllll}
\hline Option & Frequency & Percentages & $\begin{array}{c}\text { Mean } \\
\text { Value }\end{array}$ & $\begin{array}{c}\text { Standard } \\
\text { Deviation }\end{array}$ \\
\hline Strongly Disagree & 93 & 36.0 & & \\
Disagree & 75 & 28.7 & & \\
Undecided & 32 & 12.3 & 1.37 & 0.486 \\
Strongly Agree & 42 & 16.1 & & \\
Agree & 18 & 6.9 & & \\
Total & 260 & 100.0 & & \\
\hline
\end{tabular}

Table 5 showed that more than $50 \%$ responded agreed the said statements and admitted that respondents verified the items of Aslam and expressed their feelings with regards to Kohlberg's theory. While some of respondents refused to show their response. It also showed that some participants did not their willingness about the statements. Therefore it is concluded that Kohlberg's theory had positive impact on the achievement level of the learners and it would be appropriate if its application may be imposed in school level as well as higher level. Getting caught for stealing".

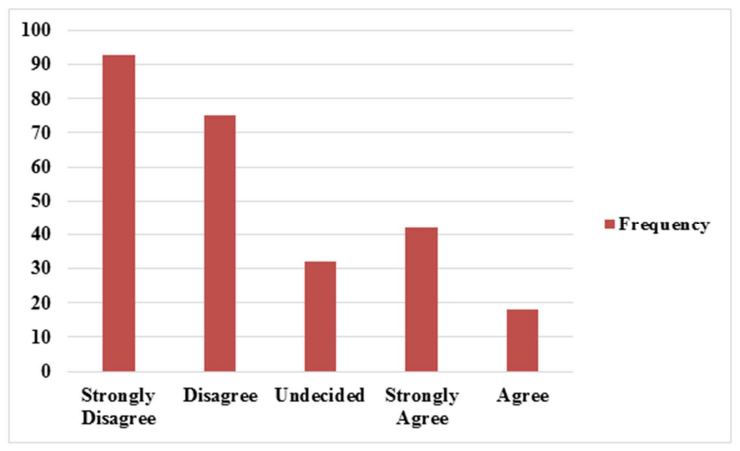

Figure 4. Does Aslam identify a decent formula for making soup form tree Bay.

Table 6. Does the rich man have any lawful correct to store food when other persons are hungry.

\begin{tabular}{lllll}
\hline Option & Frequency & Percentages & $\begin{array}{c}\text { Mean } \\
\text { Value }\end{array}$ & $\begin{array}{c}\text { Standard } \\
\text { Deviation }\end{array}$ \\
\hline Strongly Disagree & 38 & 14.9 & & \\
Disagree & 24 & 9.3 & & \\
Undecided & 23 & 8.8 & 1.42 & 0.497 \\
Strongly Agree & 59 & 22.6 & & \\
Agree & 116 & 44.4 & & \\
Total & 260 & 100 & & \\
\hline
\end{tabular}

Table 6 showed that more than $50 \%$ responded agreed the said statements and admitted that respondents verified the items of Aslam and expressed their feelings with regards to Kohlberg's theory. While some of respondents refused to show their response. It also showed that some participants did not their willingness about the statements. Therefore it is concluded that Kohlberg's theory had positive impact on the achievement level of the learners and it would be appropriate if its application may be imposed in school level as well as higher level. Getting caught for stealing.

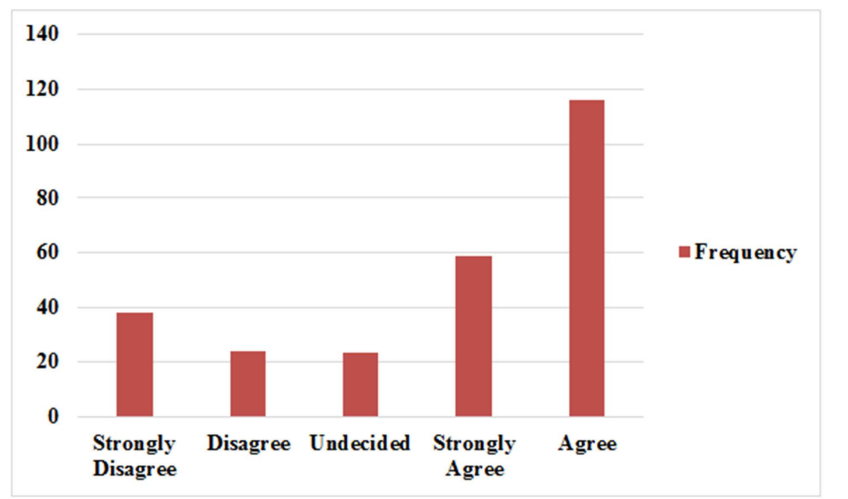

Figure 5. Does the rich man have any lawful correct to store food when other persons are hungry. 
Table 7. Is the reason of Aslam to take for himself or to giveaway for his family.

\begin{tabular}{lllll}
\hline Option & Frequency & Percentages & $\begin{array}{c}\text { Mean } \\
\text { Value }\end{array}$ & $\begin{array}{c}\text { Standard } \\
\text { Deviation }\end{array}$ \\
\hline Strongly Disagree & 25 & 10.0 & & \\
Disagree & 65 & 24.9 & & \\
Undecided & 34 & 13.0 & & \\
Strongly Agree & 49 & 18.8 & 1.85 & 0.404 \\
Agree & 87 & 33.3 & & \\
Total & 260 & 100.0 & & \\
\hline
\end{tabular}

Table 7 showed that more than $50 \%$ responded agreed the said statements and admitted that respondents verified the items of Aslam and expressed their feelings with regards to Kohlberg's theory. While some of respondents refused to show their response. It also showed that some participants did not their willingness about the statements. Therefore it is concluded that Kohlberg's theory had positive impact on the achievement level of the learners and it would be appropriate if its application may be imposed in school level as well as higher level. Getting caught for stealing.

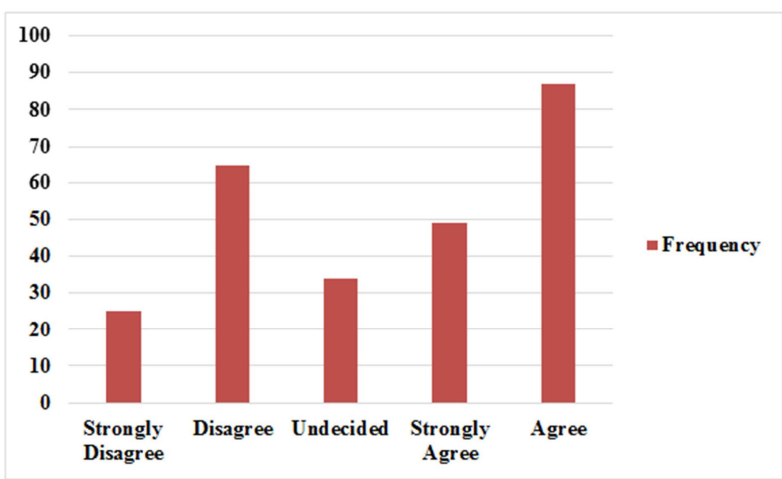

Figure 6. Is the reason of Aslam to take for himself or to giveaway for his family.

Table 8. What standards are going to be the foundation for communal collaboration.

\begin{tabular}{lllll}
\hline Option & Frequency & Percentages & $\begin{array}{c}\text { Mean } \\
\text { value }\end{array}$ & $\begin{array}{c}\text { Standard } \\
\text { deviation }\end{array}$ \\
\hline Strongly disagree & 105 & 40.6 & & \\
Disagree & 73 & 28.0 & & \\
Undecided & 29 & 11.1 & 1.32 & 0.469 \\
Strongly agree & 35 & 13.4 & & \\
Agree & 18 & 6.9 & & \\
Total & 260 & 100 & & \\
\hline
\end{tabular}

Table 8 showed that more than $50 \%$ responded agreed the said statements and admitted that respondents verified the items of Aslam and expressed their feelings with regards to Kohlberg's theory. While some of respondents refused to show their response. It also showed that some participants did not their willingness about the statements. Therefore it is concluded that Kohlberg's theory had positive impact on the achievement level of the learners and it would be appropriate if its application may be imposed in school level as well as higher level. Getting caught for stealing.

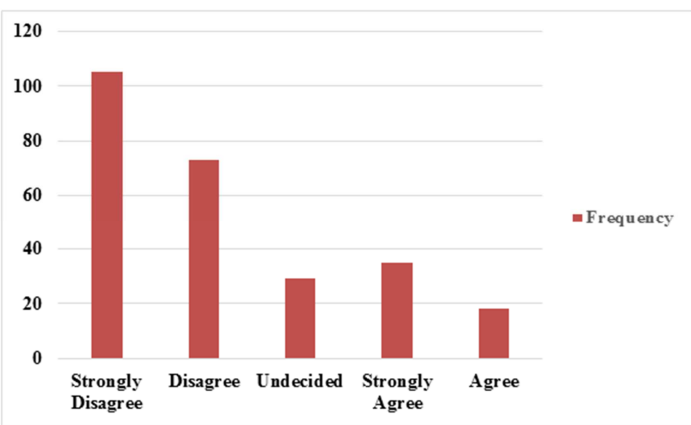

Figure 7. What standards are going to be the foundation for communal collaboration.

Table 9. Is the essence of consumption reconcilable with the liability of theft?

\begin{tabular}{lllll}
\hline Option & Frequency & Percentages & $\begin{array}{l}\text { Mean } \\
\text { Value }\end{array}$ & $\begin{array}{c}\text { Standard } \\
\text { deviation }\end{array}$ \\
\hline Strongly Disagree & 52 & 19.9 & & \\
Disagree & 49 & 18.8 & & \\
Undecided & 77 & 29.5 & 2.75 & 0.474 \\
Strongly Agree & 34 & 13.4 & & \\
Agree & 48 & 18.4 & & \\
Total & 260 & 100 & & \\
\hline
\end{tabular}

Table 9 showed that more than 50\% responded agreed the said statements and admitted that respondents verified the items of Aslam and expressed their feelings with regards to Kohlberg's theory. While some of respondents refused to show their response. It also showed that some participants did not their willingness about the statements. Therefore it is concluded that Kohlberg's theory had positive impact on the achievement level of the learners and it would be appropriate if its application may be imposed in school level as well as higher level. Getting caught for stealing.

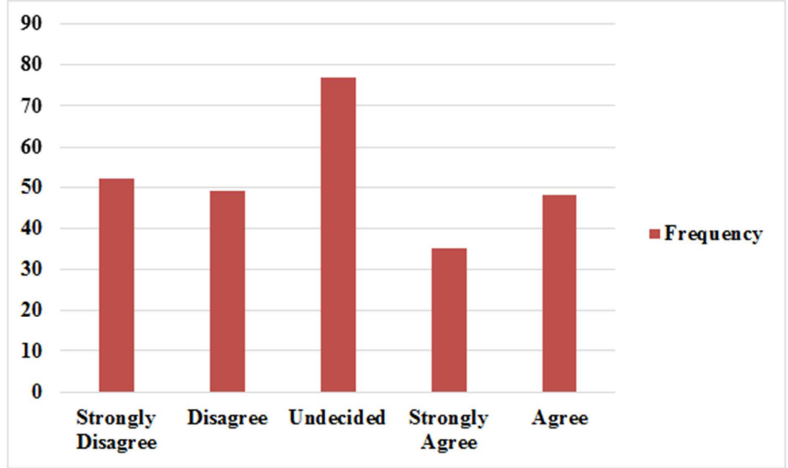

Figure 8. Is the essence of consumption reconcilable with the liability of theft?

Table 10. Does the rich man merit to be raided for being so desirous.

\begin{tabular}{lllll}
\hline Option & Frequency & Percentages & $\begin{array}{c}\text { Mean } \\
\text { Value }\end{array}$ & $\begin{array}{c}\text { Standard } \\
\text { deviation }\end{array}$ \\
\hline Strongly disagree & 60 & 12.3 & & \\
disagree & 43 & 26.1 & & \\
undecided & 36 & 12.6 & 3.23 & 1.386 \\
Strongly agree & 49 & 24.9 & & \\
agree & 72 & 24.1 & & \\
Total & 260 & 100 & & \\
\hline
\end{tabular}

Table 10 showed that more than $50 \%$ responded agreed the 
said statements and admitted that respondents verified the items of Aslam and expressed their feelings with regards to Kohlberg's theory. While some of respondents refused to show their response. It also showed that some participants did not their willingness about the statements. Therefore it is concluded that Kohlberg's theory had positive impact on the achievement level of the learners and it would be appropriate if its application may be imposed in school level as well as higher level. Getting caught for stealing”. Following table and graph shows the findings of the study.

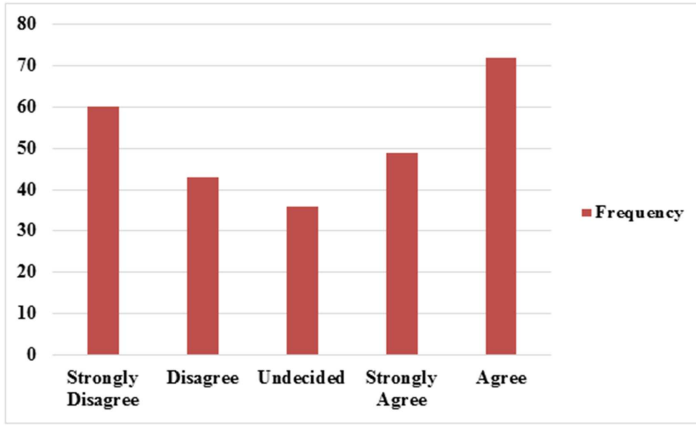

Figure 9. Does the rich man merit to be raided for being so desirous.

Table 11. Isn't private stuff an institute to allow the rich to activity the poor.

\begin{tabular}{lllll}
\hline Option & Frequency & Percentages & $\begin{array}{c}\text { Mean } \\
\text { Value }\end{array}$ & $\begin{array}{c}\text { Standard } \\
\text { deviation }\end{array}$ \\
\hline Strongly disagree & 63 & 23.0 & & \\
Disagree & 80 & 16.8 & & \\
Undecided & 39 & 13.8 & 2.94 & 1.409 \\
Strongly Agree & 37 & 18.8 & & \\
Agree & 41 & 27.6 & & \\
Total & 260 & 100 & & \\
\hline
\end{tabular}

Table 11 showed that more than $50 \%$ responded agreed the said statements and admitted that respondents verified the items of Aslam and expressed their feelings with regards to Kohlberg's theory. While some of respondents refused to show their response. It also showed that some participants did not their willingness about the statements. Therefore it is concluded that Kohlberg's theory had positive impact on the achievement level of the learners and it would be appropriate if its application may be imposed in school level as well as higher level. Getting caught for stealing.

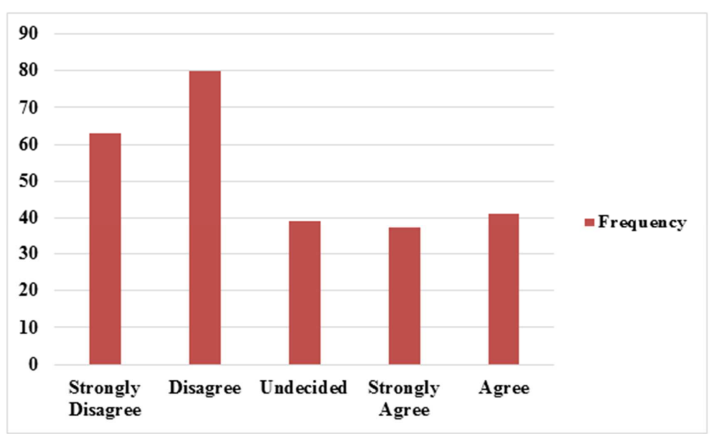

Figure 10 Isn't private stuff an institute to allow the rich to activity the poor
Table 12 Would theft bring about more entire decent for everyone worried or not?

\begin{tabular}{lllll}
\hline Option & Frequency & Percentages & $\begin{array}{l}\text { Mean } \\
\text { value }\end{array}$ & $\begin{array}{c}\text { Standard } \\
\text { deviation }\end{array}$ \\
\hline Strongly disagree & 51 & 19.5 & & \\
disagree & 68 & 26.3 & & \\
undecided & 34 & 13.1 & 2.45 & 1.481 \\
Strongly agree & 46 & 17.7 & & \\
Agree & 61 & 23.4 & & \\
Total & 260 & 100 & & \\
\hline
\end{tabular}

Table 12 showed that more than $50 \%$ responded agreed the said statements and admitted that respondents verified the items of Aslam and expressed their feelings with regards to Kohlberg's theory. While some of respondents refused to show their response. It also showed that some participants did not their willingness about the statements. Therefore it is concluded that Kohlberg's theory had positive impact on the achievement level of the learners and it would be appropriate if its application may be imposed in school level as well as higher level. Getting caught for stealing.

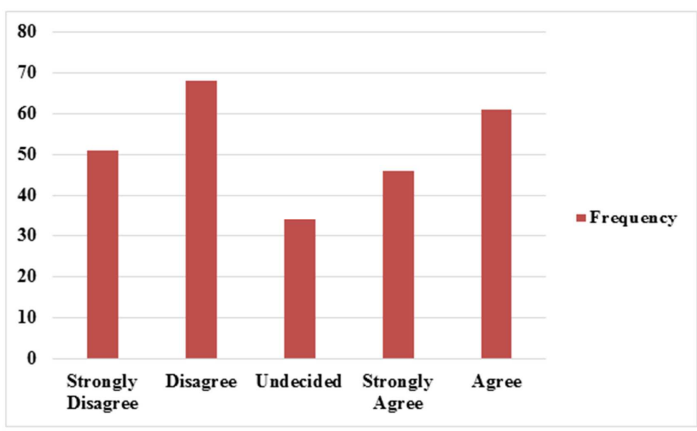

Figure 11. Would theft bring about more entire decent for everyone worried or not?

Table 13. Are laws receiving in the way of the most elementary right of any fellow of society?

\begin{tabular}{lllll}
\hline Option & Frequency & Percentages & $\begin{array}{c}\text { Mean } \\
\text { value }\end{array}$ & $\begin{array}{c}\text { Standard } \\
\text { deviation }\end{array}$ \\
\hline Strongly disagree & 98 & 37.6 & & \\
Disagree & 52 & 19.9 & & \\
Undecided & 30 & 11.5 & 2.29 & 1.292 \\
Strongly agree & 48 & 18.4 & & \\
Agree & 32 & 12.6 & & \\
Total & 260 & 100 & & \\
\hline
\end{tabular}

Table 13 showed that more than 50\% responded agreed the said statements and admitted that respondents verified the items of Aslam and expressed their feelings with regards to Kohlberg's theory. While some of respondents refused to show their response. It also showed that some participants did not their willingness about the statements. Therefore it is concluded that Kohlberg's theory had positive impact on the achievement level of the learners and it would be appropriate if its application may be imposed in school level as well as higher level. Getting caught for stealing. 
Table 14. Comparison of Teachers and Students of Urban and Rural

\begin{tabular}{|c|c|c|c|c|c|c|c|}
\hline S. $\mathbf{N}$ & Statements & Category & $\mathbf{N}$ & Mean & SD & $\mathbf{T}$ & $\mathbf{P}$ \\
\hline \multirow{2}{*}{1} & Is Aslam courageous enough to risk getting & Teacher & 60 & 2.18 & 0.97 & \multirow{2}{*}{-3.65} & \multirow{2}{*}{0.00} \\
\hline & caught for stealing & student & 200 & 3.54 & 1.34 & & \\
\hline \multirow{2}{*}{2} & Isn't it only natural for loving father to care so & teacher & 60 & 2.43 & 1.226 & \multirow{2}{*}{-3.248} & \multirow{2}{*}{0.001} \\
\hline & much for his family that he would steal? & student & 200 & 3.09 & 1.427 & & \\
\hline \multirow{2}{*}{3} & Shouldn't the community's laws be unheld? & teacher & 60 & 2.65 & 1.351 & \multirow{2}{*}{-3.524} & \multirow{2}{*}{0.001} \\
\hline & snouran l me community s raws be upnera? & student & 200 & 2.35 & 1.531 & & \\
\hline \multirow{2}{*}{4} & Does Aslam know a good recipe for preparing & teacher & 60 & 1.83 & 0.942 & \multirow{2}{*}{1.365} & \multirow{2}{*}{0.173} \\
\hline & soup form tree bark? & student & 200 & 2.43 & 1.351 & & \\
\hline \multirow{2}{*}{5} & Does the rich man have any legal right to store & teacher & 60 & 3.77 & 1.671 & \multirow{2}{*}{1.452} & \multirow{2}{*}{0.150} \\
\hline & food when other people are starving? & student & 200 & 3.71 & 1.416 & & \\
\hline \multirow{2}{*}{6} & Is the motive of Aslam to steal for himself or & teacher & 60 & 2.67 & 1.003 & \multirow{2}{*}{-3.183} & \multirow{2}{*}{0.002} \\
\hline & to steal for his family? & student & 200 & 3.63 & 1.451 & & \\
\hline \multirow{2}{*}{7} & What values are going to be the basis for & teacher & 60 & 1.85 & 0.954 & \multirow{2}{*}{-3.848} & \multirow{2}{*}{0.000} \\
\hline & social cooperation? & student & 200 & 2.28 & 1.354 & & \\
\hline \multirow{2}{*}{8} & Is the epitome of eating reconcilable with the & teacher & 60 & 2.72 & 0.940 & \multirow{2}{*}{0.254} & \multirow{2}{*}{0.800} \\
\hline & capability of stealing? & student & 200 & 2.98 & 1.461 & & \\
\hline \multirow{2}{*}{9} & Does the rich man deserve to be robbed for & teacher & 60 & 1.63 & 1.041 & \multirow{2}{*}{0.232} & \multirow{2}{*}{0.817} \\
\hline & being so greedy? & student & 200 & 3.56 & 1.384 & & \\
\hline \multirow{2}{*}{10} & Isn't private property an institution to enable & teacher & 60 & 3.27 & 1.381 & \multirow{2}{*}{-4.793} & \multirow{2}{*}{0.000} \\
\hline & the rich to exploit the poor? & student & 200 & 2.84 & 1.365 & & \\
\hline \multirow{2}{*}{11} & Would stealing bring about more total good & teacher & 60 & 3.60 & 1.167 & \multirow{2}{*}{-5.818} & \multirow{2}{*}{0.000} \\
\hline & for everybody concerned or not? & student & 200 & 2.87 & 1.699 & & \\
\hline 12 & Are laws getting in the way of the most basic & teacher & 60 & 2.32 & 1.396 & -2288 & 0023 \\
\hline 12 & claim of any member of society? & student & 200 & 2.54 & 1.480 & -2.288 & 0.023 \\
\hline
\end{tabular}

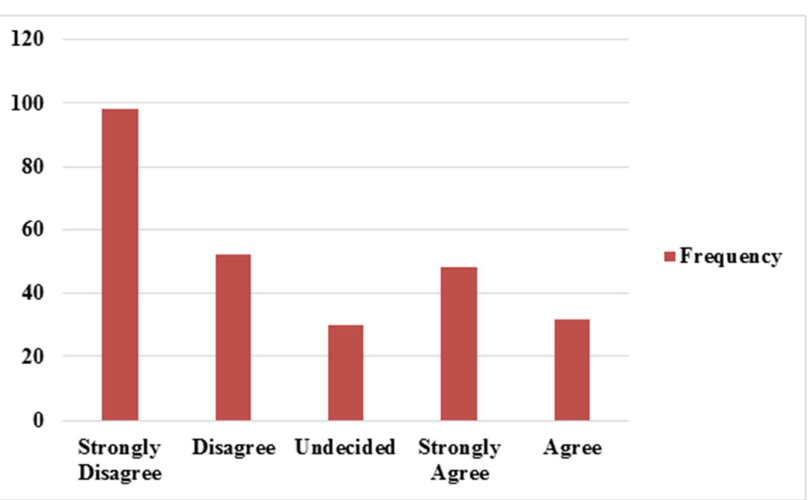

Figure 12. Are laws receiving in the way of the most elementary right of any fellow of society.

Statement 1 predicts that there is significant difference between the views of the respondents which are teachers and students of Rural and Urban schools regarding the statements "Is Aslam courageous enough to risk getting caught for stealing" of teachers and students with $\mathrm{M}=2.18,3.54$ $\mathrm{SD}=0.97,1.34$ respectively $\mathrm{t}=-3.65$ and $\mathrm{p}=.00$, Following graphs are showing the graphical representation of the collected data about the comparison of teacher and students respectively.

Statement 2 predicts that there is significant difference between the views of the respondents which are teachers and students of Rural and Urban schools regarding the statements "Isn't it only natural for loving father to care so much for his family that he would steal?" of teachers and students with $\mathrm{M}=2.43,3.09 \mathrm{SD}=1.226,1.427$ respectively $\mathrm{t}=-3.248$ and $\mathrm{p}=.001$.

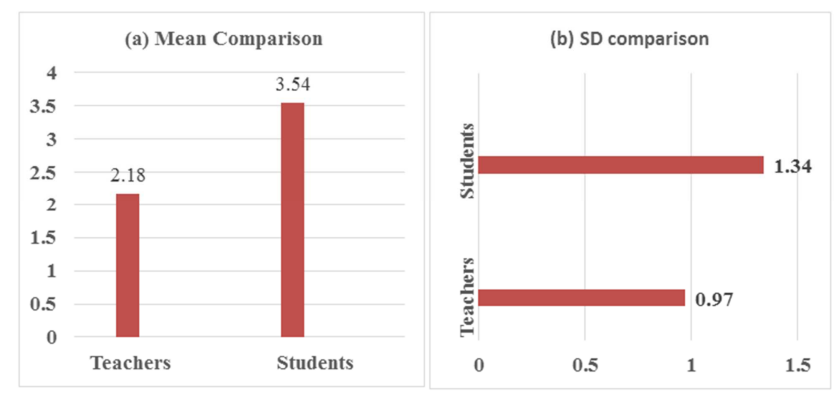

Figure 13. For statement 1 of table 14 (a) Mean comparison (b) SD comparison.
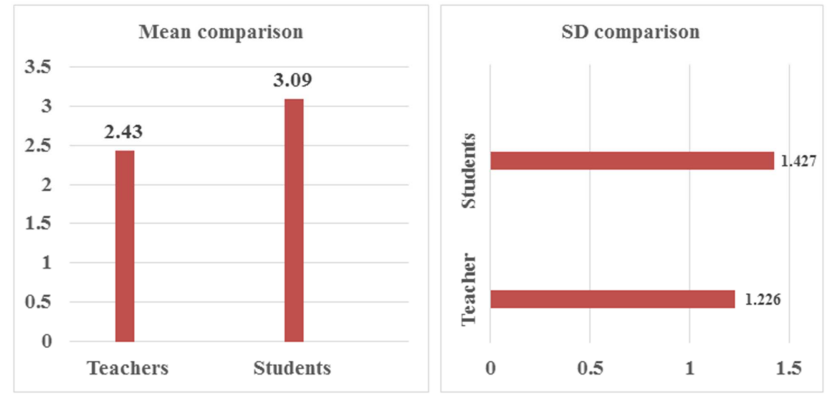

Figure 14. For statement 2 of table 14 (a) Mean comparison (b) SD comparison.

Statement 3 predicts that there is significant difference between the views of the respondents which are teachers and students of Rural and Urban schools regarding the statements "Shouldn't the community's laws be upheld?" of teachers and students with $\mathrm{M}=2.65,2.35 \mathrm{SD}=1.351, \quad 1.513$ respectively $\mathrm{t}=-3.524$ and $\mathrm{p}=.001$. 


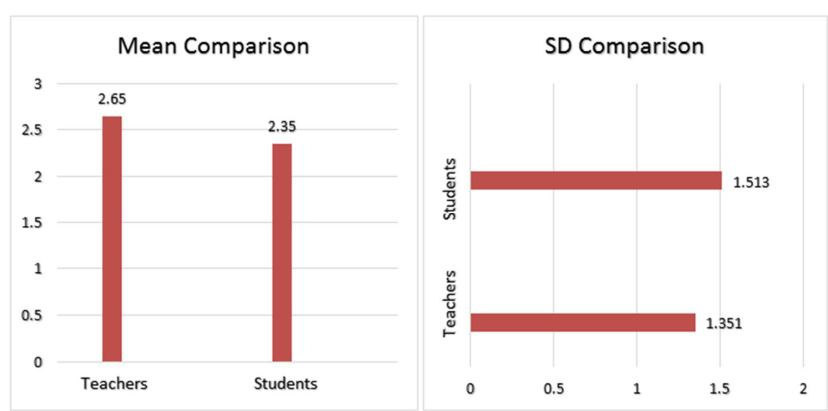

Figure 15. For statement 3 of table 14 (a) Mean comparison (b) SD comparison.

Statement 4 predicts that there is insignificant difference between the views of the respondents which are teachers and students of Rural and Urban schools regarding the statements "Does Aslam know a good recipe for preparing soup form tree bark?" of teachers and students with $\mathrm{M}=1.83,2.43$ $\mathrm{SD}=.942,1.351$ respectively $\mathrm{t}=1.365$ and $\mathrm{p}=.173$.
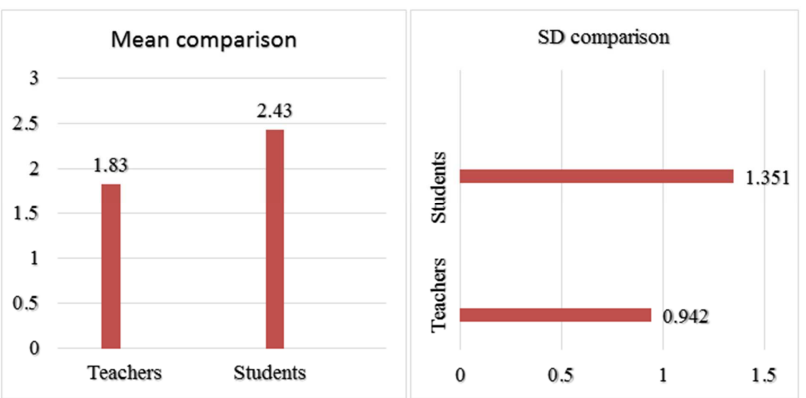

Figure 16. For statement 4 of table 14 (a) Mean comparison (b) SD comparison.

Statement 5 predicts that there is insignificant difference between the views of the respondents which are teachers and students of Rural and Urban schools regarding the statements "Does the rich man have any legal right to store food when other people are starving?" of teachers and students with $\mathrm{M}=3.77,3.71 \mathrm{SD}=1.671,1.461$ respectively $\mathrm{t}=1.452$ and $\mathrm{p}=.150$.

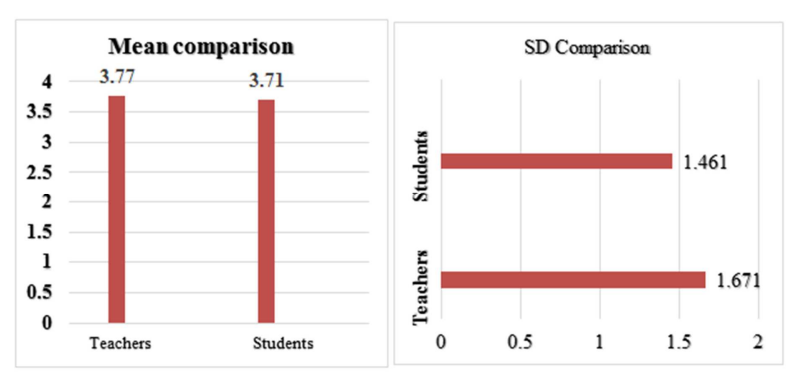

Figure 17. For statement 5 of table14 (a) Mean comparison (b) SD comparison.

Statement 6 predicts that there is significant difference between the views of the respondents which are teachers and students of Rural and Urban schools regarding the statements "Is the motive of Aslam to steal for himself or to steal for his family?" of teachers and students with $\mathrm{M}=2.67,3.63$
$\mathrm{SD}=1.003,1.451$ respectively $\mathrm{t}=-3.183$ and $\mathrm{p}=.002$.

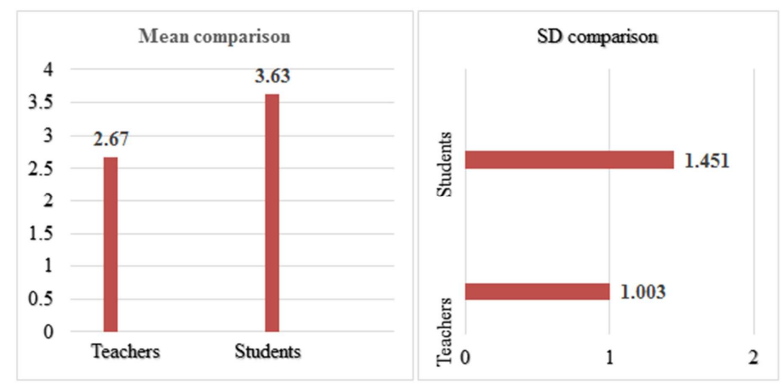

Figure 18. For statement 6 of table 14 (a) Mean comparison (b) SD comparison.

Statement 7 predicts that there is significant difference between the views of the respondents which are teachers and students of Rural and Urban schools regarding the statements "What values are going to be the basis for social cooperation?" of teachers and students with $\mathrm{M}=1.85,2.28$ $\mathrm{SD}=0.954,1.354$ respectively $\mathrm{t}=-3.848$ and $\mathrm{p}=.000$.

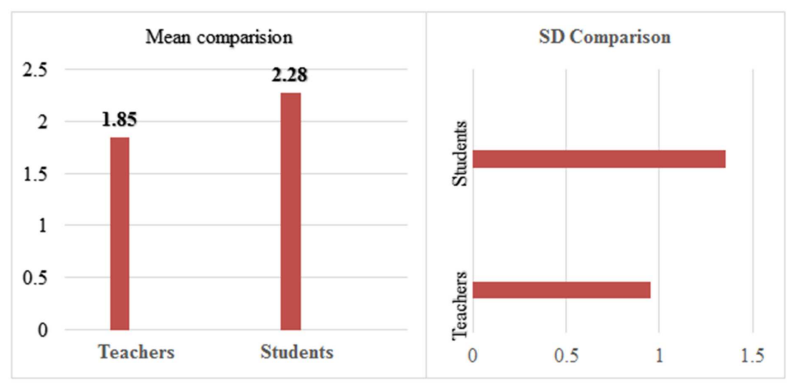

Figure 19. For statement 7 of table 14 (a) Mean comparison (b) SD comparison.

Statement 8 predicts that there is insignificant difference between the views of the respondents which are teachers and students of Rural and Urban schools regarding the statements "Is the epitome of eating reconcilable with the culpability of stealing?" of teachers and students with $\mathrm{M}=2.72,2.98$ $\mathrm{SD}=.940,1.461$ respectively $\mathrm{t}=.254$ and $\mathrm{p}=.800$.

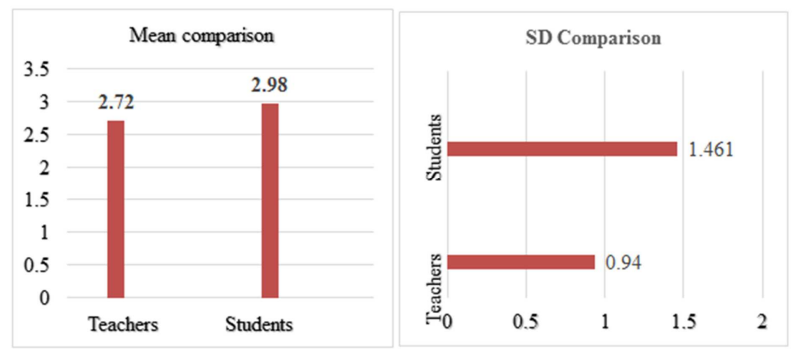

Figure 20. For statement 8 of table 14 (a) Mean comparison (b) SD comparison.

Statement 9 predicts that there is insignificant difference between the views of the respondents which are teachers and students of Rural and Urban schools regarding the statements "Does the rich man deserve to be robbed for being so greedy?" of teachers and students with $\mathrm{M}=1.63,3.56$ $\mathrm{SD}=1.041,1.384$ respectively $\mathrm{t}=.232$ and $\mathrm{p}=.817$. 


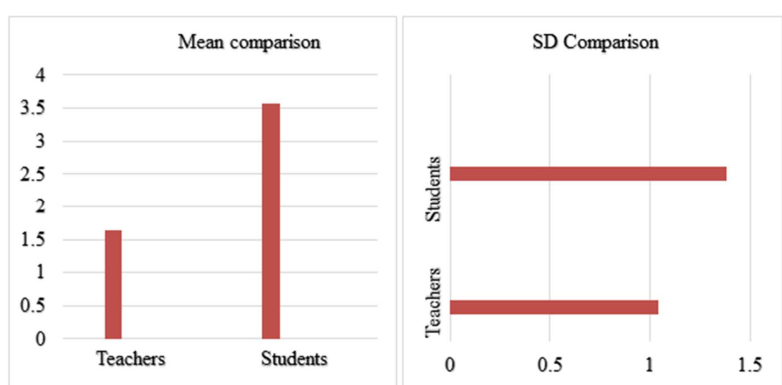

Figure 21. For statement 9 of table 14 (a) Mean comparison (b) SD comparison.

Statement 10 predicts that there is significant difference between the views of the respondents which are teachers and students of Rural and Urban schools regarding the statements "Isn't private property an institution to enable the rich to exploit the poor?" of teachers and students with $\mathrm{M}=3.27$, $2.84 \mathrm{SD}=1.381,1.365$ respectively $\mathrm{t}=-4.793$ and $\mathrm{p}=.000$.

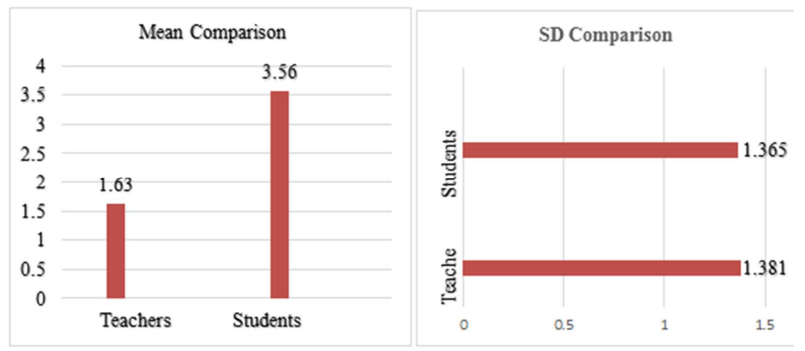

Figure 22. For statement 10 of table 14 (a) Mean comparison (b) SD comparison.

Statement 11 predicts that there is significant difference between the views of the respondents which are teachers and students of Rural and Urban schools regarding the statements "Would stealing bring about more total good for everybody concerned or not?" of teachers and students with $\mathrm{M}=3.60$, $2.87 \mathrm{SD}=1.167,1.699$ respectively $\mathrm{t}=-5.818$ and $\mathrm{p}=.000$.

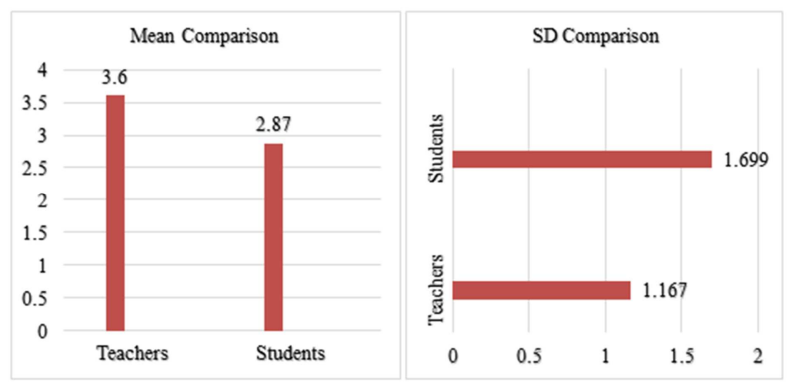

Figure 23. For statement 11 of table 14 (a) Mean comparison (b) SD comparison.

Statement 12 predicts that there is significant difference between the views of the respondents which are teachers and students of Rural and Urban schools regarding the statements "Are laws getting in the way of the most basic claim of any member of society?" of teachers and students with $\mathrm{M}=2.32$, $2.54 \mathrm{SD}=1.396,1.480$ respectively $\mathrm{t}=-2.288$ and $\mathrm{p}=.023$.

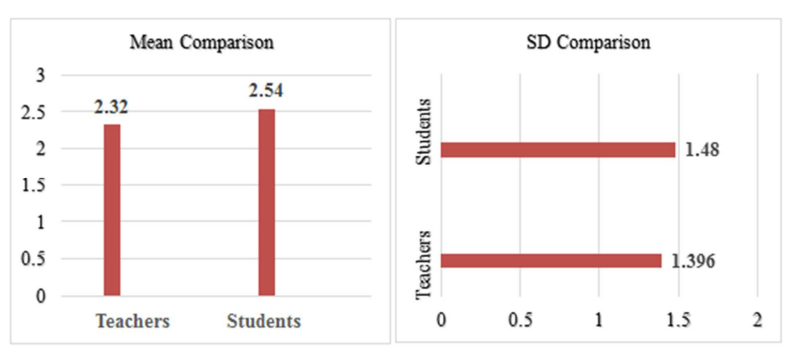

Figure 24. For statement 12 of table 14 (a) Mean comparison (b) SD comparison.

\section{Conclusion}

In this paper, we conducted the research on teachers' ethics by using the DIT to examine the moral judgment development on a sample of Secondary school teachers and students of Dera Ghazi Khan. The results revealed that Secondary school teachers and students of Dera Ghazi Khan demonstrated higher stage scores for the conventional level than for the post conventional level of the moral judgment development. The findings showed a trend to resolve the moral dilemmas in the socially approved direction. The prominence of DIT of moral judgment level obtained by the sample of this study may be interpreted as due to the conformity to the stereotypes of good behaviour and meeting with social approval which are stressed in their culture.

\section{Disclosure Statement}

The author (s) declared no potential conflicts of interest with respect to the research, authorship, and/or publication of this article.

\section{Funding}

The author (s) received no source of funding.

\section{References}

[1] Ahmed, A. M. (2009). Are religious people more prosocial? A quasi-experimental study with Madrasah pupils in a rural community in India. Journal for the Scientific Study of Religion, 48 (2), 368-374.

[2] Barchia, K., \& Bussey, K. (2011). Individual and collective social cognitive influences on peer aggression: Exploring the contribution of aggression efficacy, moral disengagement, and collective efficacy. Aggressive behavior, 37 (2), 107-120.

[3] Batool, S., \& Shehzad, S. (2019). Effect of Parenting Styles on Moral Development of Secondary School Students. Journal of Research, 13 (2), 185-197.

[4] Bebeau, M. J., \& Thoma, S. J. (2013). Moral motivation in different professions. In Handbook of moral motivation (pp. 475-498): Brill Sense.

[5] Bloom, P. (2012). Religion, morality, evolution. Annual review of psychology, 63, 179-199. 
[6] Bouhmama, D. (1984). Assessment of Kohlberg's stages of moral development in two cultures. Journal of Moral Education, 13 (2), 124-132.

[7] Bouhmama, D. (1988). Relation of formal education to moral judgment development. The Journal of psychology, 122 (2), $155-158$.

[8] Bouhmama, D. (1989). The moral judgment of Algerian University students. The Educational Journal, 6 (21), 107-134.

[9] Carpenter, T. P., \& Marshall, M. A. (2009). An examination of religious priming and intrinsic religious motivation in the moral hypocrisy paradigm. Journal for the Scientific Study of Religion, 48 (2), 386-393.

[10] Crosby III, R. G., \& Smith, E. I. (2015). Church support as a predictor of children's spirituality and prosocial behavior. Journal of Psychology and Theology, 43 (4), 243-254.

[11] Davison, M. L. (1977). On a metric, unidimensional unfolding model for attitudinal and developmental data. Psychometrika, 42 (4), 523-548.

[12] Davison, M. L., Robbins, S., \& Swanson, D. B. (1978). Stage structure in objective moral judgments. Developmental Psychology, 14 (2), 137.

[13] Emmons, R. A. (2013). Gratitude works!: A 21-day program for creating emotional prosperity: John Wiley \& Sons.

[14] Forte, A. (2013). The moral reasoning of sports management students in the United States and Italy. Journal of International Education Research (JIER), 9 (2), 177-198.

[15] Gibbs, J., Basinger, K., \& Fuller, D. (1992). Moral maturity: Measuring the development of sociomoral reflection. Hillsdale.

[16] Gibbs, J. C., Basinger, K. S., Grime, R. L., \& Snarey, J. R. (2007). Moral judgment development across cultures: Revisiting Kohlberg's universality claims. Developmental Review, 27 (4), 443-500.

[17] Hyde, L. W., Shaw, D. S., \& Moilanen, K. L. (2010). Developmental precursors of moral disengagement and the role of moral disengagement in the development of antisocial behavior. Journal of abnormal child psychology, 38 (2), 197209.

[18] Ismail, M. A.-R. (1976). Cross-cultural Study of Moral Judgments: The Relationship Between American and Saudi Arabian University Students on the Defining Issues Test. Oklahoma State University.

[19] Kohlberg, L. (1931). The philosophy of moral development: Moral stages and the idea of justice (Vol. 1): San Francisco: harper \& row.

[20] Kohlberg, L. (1958). The development of modes of moral thinking and choice in the years 10 to 16: University of Chicago.

[21] Kohlberg, L., \& DeVries, R. (1987). Child psychology and childhood education: A cognitive-developmental view: Addison-Wesley Longman Limited.

[22] Kuhmerker, L. (1971). A Bibliography on Moral Development and the Learning of Values in Schools and Other Social Settings.

[23] Looy, H. (2004). Embodied and embedded morality: Divinity, identity, and disgust. Zygon ${ }^{\circledR}, 39$ (1), 219-235.

[24] Lutjens, S. L. (2019). The state, bureaucracy, and the Cuban schools: Power and participation: Routledge.

[25] Maqsud, M. (1977). Moral reasoning of Nigerian and Pakistani Muslim adolescents. Journal of Moral Education, 7 (1), 40-41.

[26] Maqsud, M. (1998). Moral orientation of Batswana high school pupils in South Africa. The Journal of social psychology, 138 (2), 255-257.

[27] McMahon, T. R. (1992). Relationship between moral development and personality type of University undergraduates.

[28] Montoya, A. O. D. (2020). Practice and Theory in the Moral Development: Question of Awareness. Education Journal, 9 (1), 1-8.

[29] Morgado, F. F., Meireles, J. F., Neves, C. M., Amaral, A. C., \& Ferreira, M. E. (2018). Scale development: ten main limitations and recommendations to improve future research practices. Psicologia: Reflexão e Crítica, 30 (1), 3.

[30] Nettleton, J. A. (2018). Moral Reasoning, Gender and Student Participation while in College.

[31] Pazhoohi, F., Pinho, M., \& Arantes, J. (2017). Effect of religious day on prosocial behavior: A field study. The International Journal for the Psychology of Religion, 27 (2), 116-123.

[32] Piaget, J. (1976). Piaget's theory. In Piaget and his school (pp. 11-23): Springer.

[33] Pornari, C. D., \& Wood, J. (2010). Peer and cyber aggression in secondary school students: The role of moral disengagement, hostile attribution bias, and outcome expectancies. Aggressive Behavior: Official Journal of the International Society for Research on Aggression, 36 (2), 8194.

[34] Rest, J. (1974). Manual for the Defining Issues Test: An objective test of moral judgment development: University of Minnesota.

[35] Thoma, S. J. (2002). An overview of the Minnesota approach to research in moral development. Journal of Moral Education, 31 (3), 225-245.

[36] Wade, A. M. (2015). A Study of Moral Reasoning Development of Teacher Education Students in Northern Louisiana. ProQuest LLC.

[37] White-Ajmani, M. L., \& Bursik, K. (2014). Situational context moderates the relationship between moral disengagement and aggression. Psychology of Violence, 4 (1), 90.

[38] Woodward, B., Davis, D. C., \& Hodis, F. A. (2007). The relationship between ethical decision making and ethical reasoning in information technology students. Journal of Information Systems Education, 18 (2). 